\title{
Incidental pulmonary nodule frequency in Turkey
}

\author{
Nalan OGAN ${ }^{1}$ \\ Ayşe BAHA ${ }^{2}$ \\ Ebru ÖZAN SANHAL ${ }^{3}$ \\ Aslıhan ALHAN ${ }^{4}$ \\ Meral GÜLHAN ${ }^{5}$
}

Cite this arcticle as: Ogan $N$, Baha $A$, Özan Sanhal $E$, Alhan A, Gülhan $M$. Incidental pulmonary nodule frequency in Turkey. Tuberk Toraks 2019;67(3):190-6.

\section{Yazışma Adresi (Address for Correspondence)}

\section{Dr. Nalan OGAN}

Ufuk Üniversitesi Tıp Fakültesi,

Dr. Rıdvan Ege Sağlık Araştırma ve Uygulama Merkezi, Göğüs Hastalıkları Anabilim Dalı, ANKARA - TURKIYE

e-mail: nalanogan@gmail.com

OCopyright 2019 by Tuberculosis and Thorax.

Available on-line at www.tuberktoraks.org.com
${ }^{1}$ Department of Chest Diseases, Faculty of Medicine, Ufuk University, Ankara, Turkey

${ }^{1}$ Ufuk Üniversitesi Tıp Fakültesi, Gögüs Hastalıkları Anabilim Dalı, Ankara, Türkiye

${ }^{2}$ Clinic of Chest Diseases, Akcicek State Hospital, Kyrenia, Turkish Republic of Northern Cyprus

${ }^{2}$ Akçiçek Devlet Hastanesi, Göğüs Hastalıkları Kliniği, Girne, Kuzey Kıbrıs Türk Cumhuriyeti

${ }^{3}$ Department of Radiology, Faculty of Medicine, Ufuk University, Ankara, Turkey

${ }^{3}$ Ufuk Üniversitesi Tıp Fakültesi, Radyoloji Anabilim Dalı, Ankara, Türkiye

${ }^{4}$ Department of Biostatistics, Faculty of Medicine, Ufuk University, Ankara, Turkey

${ }^{4}$ Ufuk Üniversitesi Tıp Fakültesi, Biyoistatistik Anabilim Dalı, Ankara, Türkiye

${ }^{5}$ Department of Chest Diseases, Faculty of Medicine, Hitit University, Corum, Turkey

${ }^{5}$ Hitit Üniversitesi Tıp Fakültesi, Göğüs Hastalıkları Anabilim Dalı, Çorum, Türkiye

\section{ABSTRACT}

Incidental pulmonary nodule frequency in Turkey

Introduction: Pulmonary nodules are common incidental findings on computed tomography (CT). In Turkey, there is no available data about the follow-up of the frequency of incidental nodules. Our aim is to assess the frequency and size distrubition of incidental pulmonary nodule in our country.

Materials and Methods: Between January 2015 and December 2016, computed tomographies, taken of all outpatient and emergency department that recorded in the screening database were examined retrospectively. Nodules and their characteristics (number, size, density, localization) and relationship between age and gender were evaluated.

Results: The age range of the cases was mean $58.99 \pm 16.20$ years, 256 $(42.5 \%)$ were women and $347(57.5 \%)$ were men. A total of $288(48.25 \%)$ cases had 420 nodules. Solid nodule was present in 184 cases $(30.5 \%)$. The number of cases with one solid nodule was 119 (64.7\%). There were 124 solid nodules $(55.36 \%)$ of $\geq 4-<6 \mathrm{~mm}$ diameter, 64 solid nodules $(28.57 \%)$ 
of $\geq 6-<8 \mathrm{~mm}$ diameter and 36 solid nodules (16.07\%) of $\geq 8 \mathrm{~mm}$ diameter. Nodule frequency increased statistically significantly with the age $(p=0.001)$.

Conclusion: The frequency of incidental nodule was found higher than in our country than in developed countries.

Key words: Pulmonary nodule; solid; subsolid; incidental; computed tomography

\section{ÖZET}

Türkiye'de insidental pulmoner nodül görülme sıklı̆̆ı

Giriş: Pulmoner nodüller bilgisayarlı tomografi (BT)'de sık karşılaşılan rastlantısal bulgulardandır. Türkiye'de, rastlantısal nodül sıklığının izlenmesi ile ilgili mevcut veri bulunmamaktadır. Amacımız, ülkemizdeki rastlantısal pulmoner nodülün sıklığını ve boyutunu değerlendirmektir.

Materyal ve Metod: Ocak 2015-Aralık 2016 tarihleri arasında veri tabanına kayıtlı ayaktan ve acil serviste çekilmiş tüm bilgisayarlı tomografiler retrospektif olarak incelendi. Nodüller ve özellikleri (sayı, boyut, yoğunluk, lokalizasyon) ile yaş ve cinsiyet arasındaki ilişki değerlendirildi.

Bulgular: Olguların yaş aralığı $58.99 \pm 16.20$ yıl, 256 (\%42.5)'sı kadın, 347 (\%57.5)'si erkekti. Toplam 288 (\%48.25) olguda 420 nodül vardı. Solid nodül 184 (\%30.5) olguda mevcuttu. Bir solid nodülü olan olgu sayısı 119 (\%64.7) idi. Solid nodüllerin 124 (\%55.36)'ü $\geq 4-<6 \mathrm{~mm}$ çapında, 64 (\%28.57)'ü $\geq 6-<8 \mathrm{~mm}$ çapında ve 36 (\% 16.07)'sı $\geq 8 \mathrm{~mm}$ çapında idi. Nodül sıklı̆̆ı yaşla istatistiksel olarak anlamlı derecede artmıştı $(p=0.001)$.

Sonuç: Ülkemizde insidental nodül sıklı̆̆ gelişmişülkelere nazaran daha yüksek bulundu.

Anahtar kelimeler: Pulmoner nodül; solid; subsolid; insidental; bilgisayarlı tomografi

\section{INTRODUCTION}

Lung cancer is the most frequent cause of the cancer-related deaths in Turkey as in the rest of the world $(1,2)$. According to the statistical data from Turkish Ministry of Health, it is the first cause of cancer for men and fifth for women (2). Survival periods are directly related to the stage at the diagnosis and the overall survival in term of all stages are still very low despite the advances in surgical resection, radiotherapy and systemic treatment approaches (3). Therefore, there is a need for an early diagnosis-screening method that reduce the mortality rates. Studies and attempts towards this purpose have been on going for several years.

It was shown in observational studies that thorax computes tomography (CT) is more sensitive than chest radiographes $(\mathrm{CR})$ in detecting the pulmonary nodules and lung cancer $(4,5)$. after which, randomized controlled studies started with the low dose computed tomography (LDCT). The most important of these studies is the one entitled "National Lung Cancer Screening Trial" (NLST) (6). It was reported in the manuscripts published after NLST study that the most important handicap of LDCT was the large false positive rates $(7,8)$.

In Turkey, there are no available data about the follow-up of the high-risk cases and frequency of nodules, although, it is a prevalent view that the frequen- cy of incidental nodules in Turkey might be higher, as granulomatosis and occupational diseases are more frequent compared to the developed countries. The increase in the frequency of the incidental nodules might have a negative effect on LDCT in Turkey (9). Therefore, our study is intended to determine the non-calcified nodule frequency, nodule size distribution and relationship between nodule with age and gender observed in the CT exams that all patients with incidental pulmonary nodule attempted to the hospital with another kind of healthy problems.

\section{MATERIALS and METHODS}

CT taken of all outpatient and emergency department patients, recorded in the screening database of Medical Faculty Hospital of Ufuk University, a university hospital situated in Ankara city which offers health services to the neighboring cities in Central Anatolia, were examined retrospectively and cross-sectionally between January 2015 and December 2016. Ethic commission approval was taken from the same hospital for the study (20171207-3).

The inclusion criteria is; upper than 18 year old and patients who presented to our hospital because of respiratory or non-respiratory complaints and evaluated by chest $\mathrm{CT}$ scaning. The exclusion criteria by $\mathrm{CT}$ findings were determined as: being below the age of 18 , having pulmonary or pleural disease that could prevent nodule assessment (pneumonia, tuberculosis, 
fungal infection, and cavity appearance with lung cancer, mass, atelectasis, pleural effusion, pneumothorax, diffused parenchymal lung disease), nodules with calcification, metastasis, and lack of CTs taken at proper doses and/or quality. Out of 862 cases 259 were excluded from the study as they did not measure up to the admission criteria listed above leaving behind 603 cases. The relationship between the results and age and gender was studied.

\section{Imaging Technique and Image Analysis}

All CT exams were performed by using a 16-row multi-detector CT scanner (Lightspeed 16, General Electric, Milwaukee, USA) with $120 \mathrm{kVp}, 100-200$ $\mathrm{mA}, 1.25-1.5 \mathrm{~mm}$ scan thickness and pitch of 1.35 . All CT scans were reconstructed by using a medium sharp reconstruction algorithm with a $512 \times 512$ matrix and a $25-35 \mathrm{~cm}$ field of view and archived with contiguous thin sections $(<1.5 \mathrm{~mm})$. CT scans were obtained in all patients in the supine position at full inspiration. The majority of CT scans $[n=460(76.2 \%)]$ included in this study were contrast-enhanced scans. In the case of contrast-enhanced $\mathrm{CT}, 75 \mathrm{~mL}$ of contrast medium was injected at a rate of $3 \mathrm{~mL} / \mathrm{sec}$. Each study was recruited from our Picture Archiving and Communication System (Centricity PACS, GE Healthcare, General Electric, Milwaukee, USA) and loaded to a dedicated workstation including three high-resolution monitors (BARCO, Brussels). The CT findings were analyzed in the lung window setting (window level, -700 HU; width, $1500 \mathrm{HU}$ ). The analysis was conducted through the concensus of a radiologist and a pulmonologist.

CT scans were evaluated in terms of number, multiplicity (solitary, multiple), type (solid and sub-solid nodules including pure ground-glass and part-solid nodules), size (the longest diameter) and anatomical localization of pulmonary nodules. We used the classification of the previous Fleischner Society to record the data of our study (10). The detected solid nodules were classified according to the values of $\geq 4-<6$, $\geq$ $6-<8, \geq 8 \mathrm{~mm}$, and sub-solid nodules according to $<$ $5 \mathrm{~mm}, \geq 5 \mathrm{~mm}$ of solid component.

\section{Statistical Analysis}

IBM SPSS 21 package was used for the statistical analysis. Chi-square analysis was applied for categorical variables; for nodule numbers, Mann-Whitney $U$ test was used in two groups and $p<0.05$ was accepted as significant.

\section{RESULTS}

The age interval of the general population was 18-97 years (mean $58.99 \pm 16.20$ years). $256(42.5 \%)$ of the cases were women and 347 (57.5\%) were men. A sum of 420 nodules were detected on 288 CT exams of $603(48.25 \%)$ cases. $<4 \mathrm{~mm}$ nodule was determined in 40 of the CTs $(7.13 \%)$, and $\geq 4 \mathrm{~mm}$ nodule was determined in 248 of them (41.12\%). Solid nodule was present in 184 cases (30.5\%). The number of cases with one solid nodule was $119(64.7 \%)$. There were 124 solid nodules $(55.36 \%)$ of $\geq 4-<6 \mathrm{~mm}$ diameter, 64 solid nodules $(28.57 \%)$ of $\geq 6-<8 \mathrm{~mm}$ diameter and 36 solid nodules (16.07\%) of $\geq 8 \mathrm{~mm}$ diameter. The number of pure ground glass and $\leq 5$ $\mathrm{mm}$ nodules was $40(20.41 \%)$; the number of pure ground glass and $>5 \mathrm{~mm}$ nodules was $35(17.85 \%)$; the number of part-solid (solid component $\leq 5$ $\mathrm{mm})$ nodules was $24(12.24 \%)$; and the number of part-solid (solid component $>5 \mathrm{~mm}$ ) nodules was 4 $(2.04 \%)$ (Table 1$)$. Distribution of solid and sub-solid nodules according to gender was given in Table 2 . Considering the distribution of the nodules according to gender, total $112(43.75 \%)$ of the female cases included in the study had nodules. 68 of them (26.56\%) had solid nodules and 44 of them (17.19\%) had part-solid nodules. On the other hand, total 176 $(50.72 \%)$ of the 347 male cases included in the study had nodules; and 116 of them $(33.43 \%)$ had solid nodules and 60 of them (17.29\%) had part-solid nodules. While the nodule frequency was higher in males, there was no significant difference in the nodule distribution between the genders (solid nodules and part-solid nodules were $p=0.765$ and $p=0.596$, respectively).

Of the total population at equal and above the age of $55, \geq 4 \mathrm{~mm}$ nodule was determined in 182 cases $(46.67 \%)$ and $\geq 6 \mathrm{~mm}$ nodule was determined in 85 cases $(21.18 \%)$.

The most frequent nodule anatomic localization was on right hemi thorax by $61.7 \%$ and on the right upper lobe by $29.7 \%$. It was $11.5 \%$ and $20.5 \%$ on the middle lobe and right lower lobe, respectively. The nodule frequency was $18.7 \%$ on left upper lobe and $19.6 \%$ on the lower lobe.

The frequencies of the cases having one or multiple solid nodules with age are; $18(9.8 \%)$ of the cases of $<40$ years of age had nodules; $54(29.3 \%)$ of the cases of 40-59 years of age had nodules; and 112 


\section{Table 1. Classification of nodules according to age, sex by subgroups}

\begin{tabular}{|c|c|c|c|c|}
\hline Variable & & & $\mathbf{n}$ & $\%$ \\
\hline \multirow[t]{6}{*}{ Age (Year) } & Mean (interval) & & & \\
\hline & $58.9(18-96)$ & $<55$ & 213 & 35.3 \\
\hline & & $\geq 55$ & 390 & 64.7 \\
\hline & & $<40$ & 92 & 15.3 \\
\hline & & 59 & 201 & 33.3 \\
\hline & & $\geq 60$ & 310 & 51.4 \\
\hline \multirow[t]{2}{*}{ Gender } & & Female & 256 & 42.5 \\
\hline & & Male & 347 & 57.5 \\
\hline \multirow[t]{3}{*}{ Nodule presence } & Number of cases & Total & 288 & 48.25 \\
\hline & & $<4 \mathrm{~mm}$ & 40 & 7.13 \\
\hline & & $\geq 4 \mathrm{~mm}$ & 248 & 41.12 \\
\hline \multirow[t]{6}{*}{ Solid nodule } & Number of cases & Total & 184 & 30.5 \\
\hline & & Single nodule & 119 & 64.7 \\
\hline & & $\geq 2$ nodules & 65 & 35.3 \\
\hline & Number of nodules & $\geq 4-<6 \mathrm{~mm}$ & 124 & 55.36 \\
\hline & & $\geq 6-<8 \mathrm{~mm}$ & 64 & 28.57 \\
\hline & & $\geq 8 \mathrm{~mm}$ & 36 & 16.07 \\
\hline \multirow[t]{10}{*}{ Subsolid nodule } & Number of cases & Total & 104 & 17.2 \\
\hline & & Single nodule & 78 & 75 \\
\hline & & $\geq 2$ nodules & 26 & 25 \\
\hline & Number of nodules & Pure ground glass $\leq 5 \mathrm{~mm}$ & 40 & 20.41 \\
\hline & & Pure ground glass $>5 \mathrm{~mm}$ & 35 & 17.85 \\
\hline & & Partsolid (solid $\leq 5 \mathrm{~mm}$ ) & 24 & 12.24 \\
\hline & & Partsolid (solid > 5 mm) & 4 & 2.04 \\
\hline & & Multiple subsolid-pure ground glass $<5 \mathrm{~mm}$ & 9 & 4.59 \\
\hline & & Multiple subsolid- pure ground glass & 5 & 2.55 \\
\hline & & Multiple subsolid & 79 & 40.32 \\
\hline
\end{tabular}

Table 2. Frequency of nodule distribution according to gender

\begin{tabular}{|lccc|} 
& Female & Male & p \\
\hline Solid nodule & $68(26.56 \%)$ & $116(33.43 \%)$ & 0.765 \\
Subsolid nodule & $44(17.19 \%)$ & $60(17.29 \%)$ & 0.596 \\
Total & $112(43.75 \%)$ & $176(50.72 \%)$ & 0.658 \\
\hline
\end{tabular}

$(60.9 \%)$ of the cases of $\geq 60$ years of age had nodules. Considering the age threshold as 45 (24.5\%) of the cases of $<55$ years of age had nodules and 139 $(75.5 \%)$ of the cases of $\geq 55$ years of age had nod- ules. Distribution of solid and sub-solid nodules according to age was also given in Table 3. It was seen that nodule frequency increased significantly with the age $(p=0.001)$. 
Table 3. Solitary and multisolid nodule frequency by age

\begin{tabular}{lccc} 
Age & $\begin{array}{c}\text { Number of cases with } \\
\text { solitary nodules } \\
\mathbf{n}(\%)\end{array}$ & $\begin{array}{c}\text { Number of cases with } \\
\text { multiple nodules } \\
\mathbf{n}(\%)\end{array}$ & $\begin{array}{c}\text { Total } \\
\mathbf{n}(\%)\end{array}$ \\
\hline$<40$ & $14(77.8 \%)$ & $20(37.0 \%)$ & $18(9.8 \%)$ \\
$40-59$ & $34(63.0 \%)$ & $41(36.6 \%)$ & $54(29.3 \%)$ \\
$\geq 60$ & $71(63.4 \%)$ & $14(31.1 \%)$ & $112(60.9 \%)$ \\
$<55$ & $31(68.9 \%)$ & $51(36.7 \%)$ & $45(24.5 \%)$ \\
& & & $139(75.5 \%)$ \\
Total & $88(63.3 \%)$ & $65(35.3 \%)$ & $184(100 \%)$ \\
\hline
\end{tabular}

\section{DISCUSSION}

Incidentally, non-calcified lung nodules are frequently seen and usually more than one, but there is limited data on this issue. Recently in an American study, more than 200.000 adult members underwent 415.581 chest CT examinations between 2006 and 2012. The annual frequency of chest CT imaging increased from 1.3 to $1.9 \%$ for all adult members, whereas the frequency of nodule identification increased from 24 to $31 \%$ for all scans performed. (11). Other data related with this issue are from screening trials. In a systematic review in which the nodule frequency was researched in the USA, nodule frequency in high-risk smokers was found as between $8 \%$ and $51 \%$ with LDCT in consideration of eight studies (12). In the NLST study, however, $\geq 4 \mathrm{~mm}$ nodule was detected in the patients with a high risk for lung cancer (smoking for $>55$ years, smoking for $>30$ years) by $24.2 \%$ (6). To consider the other lung cancer screening studies with LDCT in the literature, this rate was found as $45.2 \%$ in the French study DEPISCAN; as $8.7 \%$ in the Danish study DLCST (> $4 \mathrm{~mm}$ ); as $30.3 \%$ in the Italian study ITALUNG, and as $2.6 \%$ in the Dutch-Belgium study NELSON (> $500 \mathrm{~mm}^{3}$ ) (13-16). In our study, $\geq 4 \mathrm{~mm}$ nodule was determined in 248 $(41.12 \%)$ cases within the whole population. In total, 224 solid nodules were present. There was an increase in incidental nodule frequency with the age. Of the total population at and above the age of $55, \geq 4 \mathrm{~mm}$ nodule was determined in $182(46.67 \%)$ cases and $\geq$ $6 \mathrm{~mm}$ nodule was determined in $85(21.18 \%)$ cases. Although not all of our cases were advanced-age smokers, thus they did not have a high risk for lung cancer, the number of nodules determined was almost twice as high as that of the NLST study, in which positivity criterion was taken as the same.
The reason why incidental pulmonary nodule is higher our study compared to the literature discussed above, could be due to the fact that the processes of granulomatosis, related to tuberculosis, occupational and environmental causes, are bigger problems in Turkey than the developed ones. The studies on the tuberculosis control have been sustained with an effective program since 2006 in particular in Turkey, but the incidence is still higher than in the developed countries (17). The use of wood, coal and organic materials for the purposes of cooking and heating in most villages and towns in Anatolia particularly and the act of smoking in the closed rooms which all family members share lead to a dramatic level of indoors air pollution (18). Outdoors air pollution is still a serious health problem in Turkey as in the whole world (19). The inadequate measures at work places cause a higher exposure to occupational dust or powder in our country than in developed ones. Yet the figures in the statistics are much lower than the existing figure (20-22). No comparison is possible with the other developing countries as no data is yet available in the literature.

In the cases with positive findings determined through NLST screening, $96.4 \%$ proved to be benign and this high false positivity led to a high number of unnecessary and additional examinations and invasive procedures (6). False positivity rates were found as $91 \%$ in DLCST study, $96 \%$ in ITALUNG and $64 \%$ in NELSON (13-15). In our study, false positivity rates could not be determined as it was retrospective and cross-sectional and the follow-up and exact diagnosis results of the cases were not known.

Attempts to lower the false positivity rates in LDCT screening are still ongoing. British Thoracic Society 
guideline supports the volumetric evaluation method to decrease the overdiagnosis and benign histologic diagnosis rate (23). American Radiology Society, however, formed the Lung-RADS guideline and took the positive nodule diameter as $\geq 6 \mathrm{~mm}$ for the screening (24). Fleischner Society has recently been republished with some important revisions on the management of solid, sub-solid and multiple nodules with the aim of decreasing the unnecessary follow-up examinations (10). According to uptated guidelines, it has been reported that as the expected risk of cancer in young patients with no history of smoking is lower than $1 \%$ (25), single, solid and calcified nodules smaller than $6 \mathrm{~mm}$ (5 mm or smaller) do not require a routine follow-up in low-risk patients; as the expected risk of cancer in high-risk patients with morphology smaller than $6 \mathrm{~mm}$ but doubtful (i.e. lobulated contour or cystic component) or with upper lobe localization or with both of them is about $1-5 \%$, it may require a twelve-month follow-up period.

According to the new recommendations, threshold value for nodule follow-up dimension has been determined as $6 \mathrm{~mm}$. In our study, 100 cases proved to have a solid nodule $(16.58 \%)$ when the threshold value was taken as $\geq 6 \mathrm{~mm}$; this rate was $21.79 \%$ for the cases $\geq 55$ years of age.

Subsolid nodules require the differential diagnosis of a wide range of diseases, including infection, organized pneumonia, inflammation, bleeding, focal fibrosis and neoplasia. Of the types of lung cancer, they are the most frequent in adenocarcinoma (26). For the recording of the data of our study, the classification of the previous Fleischner Society was used. Accordingly, it appeared that $16.9 \%$ of the cases with $>5 \mathrm{~mm}$ subsolid ground glass nodules need a long follow-up (27).

The limitations of our study; it is retrospective and no evaluation and interpretation was available according to smoking and other risk factors as the records are not complete due to the cases in which CTs were demanded from the clinics except that of the chest diseases. It is also not possible to learn how many of the nodules are malign as there are no follow-up results. We did not evaluate how many cases which could show innumerous nodule such as pneumoconiosis and metastasis. The other negative aspect is that the number of cases is relatively low as it was conducted at a single center. Moreover, because the subjects who applied to hospital are included in the study instead of a random sampling of the population, the rate might be higher than when the whole population is considered including the healthy individuals. However, a possible bias in that respect was minimized, as the cases with problems likely to cause radiologic pathology were not included in the study. On the other hand, as our study group included young and non-smoker cases, in a higher risk group the frequency of incident nodules might be further elevated compared to our measurement.

As a conclusion, the incidental nodule rate was higher than the available literature from developed countries, in our study. The attempts in resolving the difficulties in diagnosis and treatment of randomized pulmonary nodules are ongoing in clinical practice. More comprehensive and detailed studies are needed.

\section{CONFLICT of INTEREST}

No conflict of interest declared by the authors.

\section{AUTHORSHIP CONTRIBUTIONS}

Concept/Design: NO, AB, MG

Analysis/Interpretation: $\mathrm{NO}, \mathrm{AB}, \mathrm{AA}$

Data Acquisition: NO, AB, EÖS, MG

Writting: NO, MG

Critical Revision: NO, MG

Final Approval: All of authors.

\section{REFERENCES}

1. Ferlay I, Soerjomataram I, Dikshit R, Eser S, Mathers C, Rebelo $M$, et al. Cancer incidence and mortality worldwide: sources, methods and major patterns in GLOBOCAN 2012. Int J Cancer 2015;136:359-86.

2. Turkey Public Health Authority, Cancer Department, Cancer statistics of Turkey in 2014, Accessed September 21, 2018. Avalaible from: http://kanser.gov.tr/daire-faaliyetleri/kanser-istatistikleri/2106-2014-yılı-türkiye-kanseristatistikleri.htm.

3. Chansky K, Detterbeck FC, Nicholson AG, Rusch VW, Vallières $E$, Groome $P$, et al. The IASLC lung cancer staging Project: external validation of the revision of the TNM stage groupings in the eighth edition of the TNM classification of lung cancer. I Thorac Oncol 2017;12:1109-21.

4. Kaneko M, Eguchi K, Ohmatsu H, Kakinuma R, Naruke T, Suemasu $K$, et al. Peripheral lung cancer: screening and detection with low-dose spiral CT versus radiography. Radiology 1996;201:798-802.

5. Sone S, Takashima S, Li F, Yang Z, Honda T, Maruyama Y, et al. Mass screening for lung cancer with mobile spiral computed tomography scanner. Lancet 1998;351:1242-5. 
6. Aberle DR, Adams AM, Berg CD, Black WC, Clapp JD, Fagerstrom RM, et al. National Lung Screening Trial Research Team. Reduced lung-cancer mortality with lowdose computed tomographic screening. N Engl / Med 2011;365:395-409.

7. Duke SL, Eisen T. Finding needles in a haystack: annual low-dose computed tomography screening reduces lung cancer mortality in a high-risk group. Expert Rev Anticancer Ther 2011;11:1833-6.

8. Silvestri GA. Screening for lung cancer: it works, but does it really work? Ann Intern Med 2011;155:537-9.

9. Lung Cancer Screening; Turkish Lung Cancer Society, Status Report. Accessed September 21, 2018. Available from: http://www.takd.org.tr/haberler/.

10. MacMahon H, Naidich DP, Goo JM, Lee KS, Ann NC, Leung $A N C$, et al. Guidelines for management of incidental pulmonary nodules detected on CT images: from the Fleischner Society 2017. Radiology 2017;1-17.

11. Gould MK, Tang T, Liu ILA, Lee I, Zheng C, Danforth KN, et al. Recent trends in the identification of incidental pulmonary nodules. Am J Respir Crit Care Med 2015; 192:1208-14.

12. Wahidi MM, Govert JA, Goudar RK, Gould MK, McCrory DC. American College of Chest Physicians. Evidence for the treatment of patients with pulmonary nodules: when is it lung cancer?: ACCP evidence-based clinical practice guidelines $\left(2^{\text {nd }}\right.$ ed). Chest 2007;132:94-107.

13. Blanchon $T$, Bréchot JM, Grenier PA, Ferretti GR, Lemarié $E$, Milleron B, et al. Baseline results of the Depiscan study: a French randomized pilot trial of lung cancer screening comparing low dose CT scan (LDCT) and chest X-ray (CXR). Lung Cancer 2007;58:50-8.

14. Saghir Z, Dirksen A, Ashraf H, Bach KS, Brodersen J, Clementsen PF, et al. CT screening for lung cancer brings forward early disease. The randomised Danish Lung Cancer Screening Trial: status after five annual screening rounds with low-dose CT. Thorax 2012;67:296-301.

15. Lopes Pegna A, Picozzi G, Falaschi F, Carrozzi L, Falchini $M$, Carozzi FM, et al. Four-year results of low-dose CT screening and nodule management in the ITALUNG trial. J Thorac Oncol 2013;8:866-75.

16. Ru Zhao Y, Xie X, de Koning HJ, Mali WP, Vliegenthart R, Oudkerk M. NELSON lung cancer screening study. Cancer Imaging 2011;11:79-84.
17. Türkkanı MH, Yıldırım Z. Since little time remained to 2015; how far Turkey has achieved to reach the tuberculosis targets? Tuberk Toraks 2014;62:160-4.

18. Kiraz K, Kart L, Demir R, Oymak S, et al. Chronic pulmonary disease in rural women exposed to biomass fumes. Clin Invest Med 2003;26:243-8.

19. Turner MC, Krewski D, Pope CA, Chen Y, Gapstur SM, Thun MJ. Long-term ambient fine particulate matter air pollution and lung cancer in a large cohort of neversmokers. Am J Respir Crit Care Med 2011; 184: 1374- 81.

20. Akgun M, Araz O, Akkurt I, Eroglu A, Alper F, Saglam L, et al. An epidemic of silicosis among former denim sandblasters. Eur Respir J 2008; 32: 1295-1303.

21. Tor M, Oztürk M, Altın R, Cımrın AH. Working conditions and pneumoconiosis in Turkish coal miners between 1985 and 2004: a report from Zonguldak coalbasin, Turkey. Tuberk Toraks 2010;58:252-60.

22. Pala K, Türkkan A, Gerçek H, Osman E, Aytekin H. Evaluation of Respiratory Functions of Residents Around the Orhaneli Thermal Power Plant in Turkey. Asia-Pacific Journal of Public Health 2012;24:48-57.

23. Callister MEJ, Baldwin DR, Akram AR, Barnard S, Cane P, Draffan J, et al. British Thoracic Society for the investigation and management of pulmonary nodules. Thorax 2015; $70: 1-54$

24. American College of Radiology. Lung CT Screening Reporting and Data System (Lung-RADS), 2014. Accessed September 21, 2018. Available from: http://www.acr.org/ Quality-Safety/Resources/LungRADS.

25. McWilliams A, Tammemagi MC, Mayo JR, Roberts H, Liu $G$, Soghrati $K$, et al. Probability of cancer in pulmonary nodules detected on first screening CT. N Engl I Med 2013;369:910-9.

26. Maeshima AM, Tochigi N, Yoshida A, Asamura H, Tsuta K, Tsuda H. Clinicopathologic analysis of multiple (five or more) atypical adenomatous hyperplasias $(A A H s)$ of the lung: evidence for the $A A H$-adenocarcinoma sequence. I Thorac Oncol 2010;5:466-71.

27. Yankelevitz $D F$, Yip $R$, Smith JP, Liang $M$, Liu Y, Xu DM, et al. CT screening for lung cancer: nonsolid nodules in baseline and annual repeat rounds. Radiology 2015;277:55564. 